\title{
Retrenchment in South Africa: A Comparative Study
}

\author{
Hlako Jacob Choma ${ }^{1, *}$, Mahodiela Rodney Ramafalo ${ }^{2}$ \\ ${ }^{1}$ University of Venda, South Africa \\ ${ }^{2}$ Sekati Monyane Attorneys, South Africa
}

Copyright (C) 2015 Horizon Research Publishing All rights reserved.

\begin{abstract}
The paper acknowledges the meticulous work done by the researcher, Peter Ramphabana an LLB graduate from the University of Limpopo (Turfloop Campus). The purpose of the Social Plan Guidelines is to manage large-scale retrenchment and its effect on employees. The research findings identified various challenges that inhibit the effective management of retrenchments. These challenges were analysed and interpreted and a new model to effectively manage retrenchment was developed. The new model suggests that the employment relations management and corporate social investment of an organisation are utilised as vehicle to manage retrenchment effectively.
\end{abstract}

keywords Bill of Rights, Democratically Values, Redundancy or Dismissal, Retrenchment, CCMA

\section{Introduction}

The Bill of Rights enshrines the rights of all people in our country and affirms the democratic values of human dignity, equality and freedom. The key consideration among these rights and democratic values are the rights for Labour practices that are crucial for any democratic society. On the other hand, sustainable development and social peace are not possible without Labour practice in the workplace. Employees and employers rights are generally dealt with and studied with Labour Relations Rights.

Despite consideration to be given into international law and to some extent to foreign Law in interpretation of the Bill of Rights, South African Labour Law students and experts have very often overlooked the co-operative perspective. The value of well-known comparative experiences in foreign jurisdictions should never be underestimated. It should however not be over-estimated either.

Both South African and English legal systems, acknowledge that redundancy or dismissal for operational requirements may be a reason for dismissal. Under both legal systems an employee has to be distinguished for an independent contractor and both systems come to the conclusions that the answer depends on the relevant circumstances of the individual case.

\section{Definition of Redundancy or Dismissal for Operational Requirements}

The definition of redundancy under English Labour Law is contained under section 139 (1)1, whereas under South African Labour Law system the definition of dismissal for operational requirements is contained under section 2132. The English Labour Law provides that an employee shall be taken being dismissed by reason of redundancy in case of a cessation of business, where the employer moves his place of business or in a situation of surplus Labour 3 or have diminished or expected to diminish, while the South African Labour Law take a different approach for the definition of redundancy or dismissal for operational requirements.

Under South African Labour Law, section 2134, defines the term operational requirements to mean requirement based on the economic, technology and structural or similar need of an employee, and Code of Good Practice elaborates further to define operational requirements as follows:

Economic reasons are these reasons that relate to financial management of the enterprise, Technology reasons refer to the introduction of new technology that affects work relationships either by making jobs redundant or by requiring employee to adapt to the new technology or a consequential restructuring of the workplace, Structural reasons relate to the redundancy posts consequent a restructuring of the employer's enterprise.

Under the English Labour Law redundancy is governed by various statutes and legislations, while in South Africa the position is different in that it is regulated in terms of Labour Relations Act5. The main legislation governing redundancy under English Labour Law is the Trade Union and Labour Relations (Consolidation) Act 6, The Collective Redundancies and transfer of undertaking (protection of employment) regulations 1996 (SI 1996/2587), regulations

\footnotetext{
1 Employments Rights Act 1996.

2 Labour Relations Act 66 of 1995.

3 Selwyn, N, at 438 et seq, Bowers, n, 34 act pp 369 et seq.

4 Employments Rights Act 1996.

5 Labour Relations Act 66 of 1995

6 Trade Union and labour Relations (consolidation) Act 1992
} 
1999 and regulations 2007 and Employment Rights Act7, while Labour Relations Act 8 is the only South African Legislation that deals with dismissal for operational requirements.

The meaning of redundancy under English Perspective derives from redundancy payment Act and the other from European Law, which under South Africans perspective it derives from the International Labour Organization, which was later implemented in section 213 of the LRA9.

\section{The Legal Requirement for Dismissal Based on Operational Requirements}

Under the English Law Perspective, section 188 10, provides that an employer who is proposing to dismiss as a redundant 20 or more employees at one establishment within the period of 90 days or less must consult "in good time" and in any event at least 30 days before the first of dismissals takes effect (which means before giving notice to the first dismissal, while in South African Labour Law provides that, when the employer contemplates dismissal for operational requirements, the employer must issue a written notice inviting the other consulting party with it and disclose in writing all relevant information relating to dismissal in terms of section 189 (3) 11

The English Labour Law provides that, statutory consultation and notification procedures apply only in dismissals concerning 20 or more employees and extend over 90 days. In South Africa for section 189A dismissals, the consultation period may last up to 60 days comparatively less onerous for employers. The most common waiting period, according to Van Niekerk 12 is 30 days. The length of consultation periods in other countries compare favourably (i.e. are in alignment) with the requirements of the LRA, even where section 189A of the Act and its 60 day moratorium applies. The length of consultation under the LRA is not unduly onerous for South Africa's employers compared with that in many other countries.

Under English Labour Law the right to justify dismissal for redundancy is created by Statutes, e.g. there is no statutory remedy for unfair dismissal until an employee has served a qualifying period of one year, while the position of South African Labour Law is different in that the right for dismissal based on operational requirement is a fundamental right which give an employee right to a constitutional claim.

Both legal systems acknowledge redundancy as a reason why a dismissal may be held fair on procedurally aspect in that the employer must invite or consult employees when contemplating to dismiss for operational requirements.

7 Employment Rights Act 1996

8 Labour Relations Act 66 of 1995

9 Labour Relations Act 66 of 1995

10 Trade Union and labour Relations 1992

11 Labour Relations Act 66 of 1995

12 Andre Van Niekerk, regulating flexibility and small business: revisiting the LRA and BCEA
Although the definition of when a redundancy is given may differ, the basic idea is that where a business closes or moves or where a smaller workforce is required, it must be possible for an employer to dismiss employees without being considered unfair. Furthermore both legal systems take into account that an offer of alternative employment may render a dismissal unfair, since in this case a dismissal would not be inevitable. Other common aspects between South African and English Labour Law are fair selection process and the principle of "the last in and first out".

Under the English Labour Law it is up to the management to determine the selection criteria which have to be fair and reasonable, while employers in South Africa are generally given a free hand when it comes to selecting employees for retrenchment, and the Courts intervene only to ensure that such dismissal has not been used been as an opportunity to discard employees for reasons unrelated to operational requirements.

\section{Collective Redundancy or Large-scale Dismissal Based on Operational Requirements}

Section 188 of Trade Union and Labour Relations, regulate dismissal for collective redundancy under English Labour Law whereas section 189A of the LRA, regulate the dismissal for operational requirements where it involves more than 10 employees. However, the above statement means same, but only the interpretation words differ.

Under English Labour Law, an employer who is proposing to dismiss as redundant 20 or more employees at one establishment within the period of 90 days must consult in a good time and in any event at least 30 days before the dismissals takes effect, while the position of South African Labour Law is different, in that the employer can dismiss as redundant from 10 employees or more at once, unlike from 20 employees as stated under English Law perspective. Both legal systems distinguish between the small scale by employer and large-scale dismissal by the employer. Both legal systems acknowledges that the consultation requires consultations to be about avoiding the dismissals, reducing the numbers to be dismissed and mitigating the consequences for the dismissal and must be undertaken with the view to reaching agreement with appropriate representatives.

Both English and South African Labour Law, further acknowledges that the representatives have to be informed at the beginning of the consultation period in writing about the reasons for the proposals, the number, and description of employees whom it is proposed to dismiss, the total number of employees of any such description employed by the employer establishment, the proposed method of carrying out the dismissals with due regard to any agreed procedure, including the period over which the dismissals are to take effect and the proposed method of calculating the redundancy payment if this differs from statutory sum. 
Under English Law individual notices of dismissal for redundancy may not normally be issued in a collective redundancy situation until the process of consultation has been completed in accordance with these statutory requirements. The required notice period will depend on what an individual's contract of employment provides for, subject to minimum periods set out in section 86 , while the position in South African Labour Law is different in that there is a little protection of individual dismissed for operational requirements.

Both legal systems recognize the concept of severance payment in settlement agreement; however the English Labour Law has legislation that regulates redundancy payment, specifically unlike South Africa. The main legislation governing redundancy under English Labour Law are five, namely, The Trade Union and Labour Relations 13, The Collective redundancy and Transfer of Undertakings 14, The Employment Rights Act15, Regulations 1999 and The Collective Redundancy Regulations 2006, while under South African Labour Law only Labour Relations Act 16 regulate dismissal for operational requirements under section 189 .

South African regulations pertaining to the dismissal for an operational requirement differs fundamentally from those of European Union and English Labour Law as far as collective rights and obligations are concerned. Under English Law a retrenched worker could expect to receive inter alia income for support, housing benefit, child benefit and family tax credit, whereas the position of South African Labour Law is different. Both legal systems acknowledge that the employee who is dismissed for dismissal for operational requirements or redundancy is entitled to severance payment.

Regulating the concept of dismissal for operational requirements in a way, which is fitting for South Africa at present, should be explored. It is submitted that we have not arrived at a point where we can say the current regulations of dismissal for operational requirements in South Africa is the most appropriate, that its results in the minimum amount of legal uncertainty and that it fulfils the primary object of our Labour Relations Act, which among other strives to give effect to the right to fair Labour practice as contained in section 23 of the South African Constitution 17.

Section 1 of the LRA18 states that the purpose of the Act is to advance economic development, social justice, Labour peace and democratization of the workplace by fulfilling the primary object of the Act. These include the aim of promoting orderly collective bargaining and employee participation in decision making in the workplace.

The present definition of "operational requirement" as found in section 213 of the LRA 19, which refers to needs of

13 Trade Union and labour Relations 1992

14 The Collective redundancy and Transfer of Undertakings 1996

15 The Employment Rights Act 1996

16 Labour Relations Act 66 of 1995

17 The Constitution of the Republic of South Africa Act 108 of 1996

18 Labour Relations Act 66 of 1995

19 Labour Relations Act 66 of 1995 the employer, is clearly problematic. An employer could for example argue that it is operational requirements to dismiss employees. It is submitted that even though a purposive interpretation of the Act should prevent such a rationalization from being accepted, it would for the sake of the legal certainly be better to expressly limit the definition of "operational requirements"

In South Africa, an "employee" is defined narrowly by our legislation and the Courts has utilized the dominant impression test to determine the status of individual in cases of doubt. It is suggested that the notion of an "employee" must be interpreted widely so as to achieve the object and purpose of the LRA, as defined in section 1 thereof.

The dissertation has accepted the primary goal of dismissal for operational requirements provisions (essentially being that of employee protection) and has regarded this as indispensable for achieving the fulfilment of the right to fair Labour practices. In order to ensure justice towards all parties, it is however necessary that these statutory measures should persistently be scrutinized and debated.

The dissertation further attempted to take up this challenge and to try to fill the gap by investigating workers and employer's right on the aspect of dismissal for operational requirements, especially when a single employee who is not a member of trade union or represented during the process of dismissal for operational requirements in the light of foreign, but mostly international law and jurisprudence

Much more research is still needed on dismissal for operational requirements and greater attention should be given to dismissal for operational requirements when a single employee who is not a member of trade neither union or represented during the process of dismissal for operational requirements, considered against the background of international law that inspired our Bill of Rights 20 and Labour Legislation. Consideration should also be given to international jurisprudence as well as to the law and jurisprudence of the other democratic countries in order to promote the concept of dismissal for operational requirements in our own law and jurisprudence

Section 189 of the LRA as amended deals with the termination of employment contract for operational requirements. The section prescribes a consultation process to be followed. In 2002 the LRA was amended and introduced section 191 (12)21. This section gives a single employee who was retrenched a choice whether to refer a dispute to the CCMA for arbitration or the Labour Court for adjudication.

The section states: "If an employee is dismissed by reason of the employer's operational requirements following a consultation procedure in terms of section 189 that applied to that employees only, the employee may elect to refer the dispute either to arbitration or to the Labour Court.'

20 A Bill of Rights for a new South Africa, prepared by the Constitutional Committee of the ANC

21 Labour Relations Act 66 of 1995 
From the wording it is clear that section 191(12) applies where a single employee was consulted and subsequently retrenched. It is not applicable where there was more than one employee retrenched. If more than one employee was retrenched, the CCMA has no jurisdiction, meaning the employees must refer the dispute to the Labour Court.

If a single employee was retrenched he/she has a choice to either refer the dispute to the Labour Court for adjudication or to the CCMA for arbitration. The Labour Court had an opportunity to interpret section 191 (12) in an unreported matter of Rand Water v Bracks \& others .

The court considered the section in the light of the explanatory memorandum of 2002 , which stated that the CCMA was to deal with relatively simple cases of individuals who may not be able to afford the costs of labour court litigation. The court makes an observation that a matter does not become complex merely because of the number of employees retrenched but the facts of a matter determine its complexity.

The court regards the substantive issues as possibly less complex and therefore the CCMA should deal with that. The court interprets the section to mean that the employee may only refer such a dispute to the CCMA if the substantive issues are in dispute only. Because the section says, "Following a consultation procedure in terms of section 189, the court said that it was the intention of the legislator that section 191 (12) only allows a single employee to refer a dispute on substantive issues to the CCMA." Any dispute on the procedure must be referred to the Labour Court for adjudication. In the light of this judgment it seems to be safer to refer all retrenchment disputes to the Labour Court after conciliation failed.

A recent judgment: if a single employee has been retrenched and he or she intends to challenge the procedure relating to the dismissal, the CCMA no longer has jurisdiction to adjudicate on the dispute. The unreported Labour Court matter of Rand Water v Bracks \& others 22 holds that the CCMA only has jurisdiction when the substantive fairness of a single employee's dismissal for operational requirements is in issue. Any dispute on the procedure must be referred to the Labour Court for determination

The case concerned an employee (Miss Swart) who was employed by Rand Water as a GIS Specialist in its Scientific Services Division. Rand Water had two GIS sections, one in the Scientific Services Division and the other in the Engineering Services Division. Swart's letter of appointment included that statement that her appointment would be "subject to the changing requirements of Rand Water."

During June 2002 Rand Water considered a merger of its Engineering Services Division with the Water Treatment and Technology Divisions. If this happened Swart would have been required to move from the former division to the latter. Correspondence was exchanged between Swart and Rand

22 Bracks NO and Another v Another Rand Water and Another (JA/2/08) (2010) ZALAC4
Water on this issue and various meetings took place, culminating in Rand Water making an offer to Swart that she be transferred to the Engineering Services Division. Her salary and conditions of employment were to remain the same. Despite this, Swart refused to accept the offer and in May 2003 Rand Water wrote to Swart terminating her services. Swart referred the matter to the CCMA for conciliation and when it remained unresolved she referred it to arbitration. The commissioner found in Swart's favour and it was on the basis of this award that Rand Water appealed to the Labour Court.

The relevant and important aspect of the Labour Court's judgment relates to the question of whether or not the CCMA had jurisdiction to hear the dispute in the first place. Rand Water argued that it did not, stating that in terms of section 191 (12) of the Labour Relations Act the jurisdiction of the CCMA to hear single retrenchment dismissals is restricted.

In terms of section 191 (12), if an employee is dismissed by reason of the employer's operational requirements following a consultation procedure in terms of section 189 that applied to that employee only, the employee may elect to refer the dispute either to arbitration or to the Labour Court.

Rand Water's representative argued that on a proper interpretation of this section:

It is clear that the CCMA has jurisdiction only when the substantive fairness of a single employee's retrenchment is in issue, and By inserting the phrase "following a consultation procedure in terms of section 189, the legislature intended to grant specific jurisdiction to the CCMA for single retrenchments only when the substantive issues surrounding the dismissal were in dispute".

He premised his argument on a literal reading of the section, stating that if the legislature intended the CCMA to have general jurisdiction to arbitrate disputes involving a single employee where both substance and procedure were in issue, section 191 (12) would not have contained the words highlighted above. In coming to its decision the Labour Court relied on the established canon of statutory interpretation, that in interpreting a particular section of an Act, effect must be given to all the words encapsulated by that section. In interpreting the phrase "following a consultation procedure in terms of section 189", the Labour Court found that the language of section was peremptory in that the word "following" (in the context of the section) indicated causation that is a consequence or a result.

Essentially the Labour Court interprets the section to mean that after adhering to the requirements of a fair procedure as laid out in section 189, if a retrenchment is still in dispute (and logically it would only be in dispute for substantive reasons), then the aggrieved employee may refer the matter to the CCMA for arbitration.

The court maintained that this interpretation is further supported by the explanatory memorandum to the 2002 amendment (which introduced section 191 (12) of the LRA), which indicated that this section's introduction was designed to allow the CCMA the jurisdiction to deal with relatively simple cases involving the dismissal of an individual who 
may not be able to afford the costs of Labour Court litigation.

The court held further that the issue of whether or not an employer has substantive cause to retrench an employee is more often not relatively clear cut, far less complicated an issue than the factual web which may need to be unpacked when dealing with procedural issues. The latter, so the court reasoned is something on which the Labour Court is far better equipped to adjudicate.

It is suggested that this judgment, although favourable for employers, is open to criticism as it ultimately fails to recognize what the LRA and CCMA seek to achieve cheap, easy and accessible dispute resolution for those who are unable to afford the costs of Labour Court litigation.

The CCMA is a forum that was created to mediate on and resolve disputes that arise between employers and employees. In the area of dismissals based on operational requirements, its jurisdiction should not be limited to only those disputes relating to the reasons for a dismissal. To restrict the CCMA's jurisdiction in this way fails to promote the LRA's objective of accessible dispute resolution.

It remains to be seen whether this judgment will remain authoritative or whether an employee with the requisite means will tackle it head on. I further submit that the legislature has not succeeded by 2002 amendment to resolve the problems created by different interpretation of section 189 of the LRA. A dismissal for operational requirements, like dismissal for incapacity is regarded as a no-fault dismissal. The employer is required to effect dismissal for operational reason in accordance with a fair procedure and for a valid reason.

\section{Conclusion and Recommendation}

The introduction of the Labour Relations Act of 1995 was a turning point in the formal regulation of the employment relations in our country. In spite of such a significant move in changing our law, trade unions and understandably so, were still not content with certain provisions of the new Labour Relations Act including section 189 which deals with dismissals based on operational reasons. On the other hand the employers also harboured certain concerns about the new Labour Relations Act.

It was seen to be taking away their rights and giving more to employees. These fears should be understood against the background of the employer's history of domination over employees under common law and of being protected by legislation under the apartheid regime.

It is fair to say that the Labour Relations Act provides primarily protection against procedurally unfair retrenchments. The courts have also been willing to impose tight set of standard when it comes to procedural fairness of retrenchments. The new amendments to the Labour Relations Act, 66 of 1995 must be seen as a compromise between the social partners. The Labour movement in particular COSATU has not been entirely satisfied with the current law of retrenchments hence its demand for the new amendments to be introduced to tighten up on the duty to consult. It would appear that most of their concerns were addressed by the amendments.

The important role played by our courts in interpreting from time to time these pieces of legislation as promulgated and thus developing jurisprudence, giving clarity and certainly in some areas must be commended. Equally the influence of the ILO Conventions and Recommendations in shaping our retrenchment law, having gone through the rough history of our industrial relations in our country deserves recognition.Currently our labour law in general and dismissal law practices in particular can be seen as one of the best in the world.

\section{REFERENCES}

\section{STATUTES}

[1] Employments Rights Act 1996.

[2] Labour Relations Act 66 of 1995.

[3] Employments Rights Act 1996.

[4] Trade Union and labour Relations 1992

[5] The Constitution of the Republic of South Africa Act 108 of 1996

[6] A Bill of Rights for a new South Africa, prepared by the Constitutional Committee of the ANC

\section{CASE LAW}

[7] Bracks NO and Another $\mathrm{v}$ Another Rand Water and Another (JA/2/08) (2010) ZALAC4

\section{AUTHOR}

[8] Selwyn, N, at 438 et seq, Bowers, n, 34 act pp 369 et seq. 